\title{
The Constitutionality of Notice by Publication in Tax Sale Proceedings
}

The statutes of all fifty states and the District of Columbia ${ }^{1}$ contain provisions for the annual sale of real estate for which the property taxes remain unpaid. 2 The sale is followed by a redemption period during which the owner may recover his property by paying the back taxes, plus interest at a substantial rate. If the property goes unredeemed, the tax sale purchaser is issued a tax deed and the owner loses all interest in the property. This result will often be very harsh,

1. Ala. Code Ann. tit. 51, $\$$ 249-338(1) (Supp. 1973); Alaska Stat. Ann. $\$ \$ 29.53 .200$ .390 (Supp. 1974); Ariz. Rev. Stat. ANn. $\$ \$ 42-381$ to -473 (Supp. 1974); Ark. Stat. ANn. $\$ \$ 84-1101$ to -1336 (Supp. 1971); Cal. ReV. \& TAX. Code $\$ \$ 3351-4379$ (West Supp. 1974); Colo. Rev. Stat. ANN. $\$ \$ 39-11-101$ to -12.113 (1973); Conn. Gen. Stat. Rev. $\$ \$ 12-155$ to -I59 (1973); DEL. CoDE ANN. tit. 9, $\$ \$ 8701-8779$ (Supp. 1974); D.C. CodE ANN. $\$ \$ 47-1001$ to -1018 (1973); Fla. Stat. ANN. \$\$ 197.012-.441 (Supp. 1974); GA. CodE ANN. \$\$ 92-8101 to -8316 (1974); HawaII Rev. STAT. \$§ 246-55 to -63 (Supp. 1974); IDaho CodE ANN. \$§ 63-1114 to -1144 (Supp. 1974); Ill. ANN. STAT. ch. 120, $\$ \$ 705.752 .1$ (Smith-Hurd Supp. 1974); INd. Stat. ANN. $\$ \$ 6-1-56-1$ to -57-16 (Supp. 1974); Iowa Code ANN. $\$ \$ 446.1-448.17$ (Supp. 1974); Kan. Stat. ANN. $\$ \S 79.2301$ to $-2416 d,-2801$ to -2810 (Supp. 1974); Ky. REv. Stat. ANN. $\$ \$$ 134.430-.570 (Supp. 1974); LA. Rev. Stat. ANN. \$\$ 47:2171-:2230 (Supp. 1975); ME. REv. STAt. ANN. tit. 36, \$\$ 1071-1084 (Supp. 1974); MD. ANN. Code art. 81, \$\$ 70-123C (Supp. 1974); Mass. Ann. Laws ch. 60, $\$ \$ 37-84$ A (Supp. 1974); Mfich. Comp. Laws Ann. $\$ \$ 211.60-$ .157 (Supp. 1974); MInN. Stat. ANN. $\$ \$ 280.001-284.28$ (Supp. 1974); Miss. Code ANN. $\$ \$$ 27-41-55 to $-45-29$ (Supp. 1974); Mo. Ann. Stat. $\$ \$ 140.010-141.970$ (Supp. 1975); MonT. Rev. Codes Ann. \$\$ 84-4101 to $-41-104$ (Supp. 1974); Neb. Rev. Srat. ANN. \$\$ 77-1801 to -1941 (Supp. 1974); Nev. REv. STat. $\$ \S 361.565-620$ (1957); N.H. REv. STAT. ANN. \$§ 80:18:42-a (Supp. 1973); N.J. Stat. ANN. $\$ \$ 54: 5-19$ to -129 (Supp. 1974); N.M. STat. ANN. \$§ 72-31-60 to -74 (Special Supp. 1974); N.Y. Real Prop. TAX Law $\$ \$ 1000-1094$ (McKinney Supp. 1974); N.C. Gen. Stat. ANN. \$\$ 105-369 to -378 (Supp. 1974); N.D. CENT. Code §§ 57-24-01 to -30.05 (Supp. 1973); OHIO REv. CoDE ANN. \$\$ 5721.01-5723.19 (Page Supp. 1973); OkLA. Stat. ANN. tit. 68, \$\$ 24311-24351 (Supp. 1974); ORE. Rev. Stat. $\$ \$ 312.005$. .990 (1973); PA. Stat. ANN. tit. 72, $\$ S 5860.101-6154.3$ (Supp. 1974); R.I. Gen. Laws ANN. $\$ \$ 44-9.1$ to -46 (Supp. 1974); S.C. Code ANN. $\$ \$ 65-2761$ to -2811 (Supp. 1974); S.D. CoMp. LAws ANn. $\$ \$ 10-23-1$ to $-26-10$ (Supp. 1974); TENn. Code Ans. $\$ \$ 67-2001$ to -2046 (Supp. 1974); Tex. Rev. Civ. Stat. ANN. arts. 7319-7345e (Supp. 1974); Utah Code ANn. \$\$ $59-10-29$ to $-47,-56$ to -65 (1974); VT. STAT. ANN. tit. 32, \$§ 5251-5263 (Supp. 1974); VA. CodE ANN. $\$ \$ 58-1117.1$ to -1117.11 (Supp. 1974); WASH. REv. Code ANN. $\$ \$ 84.64 .010-460$ (Supp. 1974); W. VA. Code ANN. $\$ \$ 11 A-3-1$ to $-4-41$ (1974); WIs. STAT. ANN. $\$ \$ 74.33-75.70$ (Supp. 1974); Wyo. Stat. ANN. $\$ \$ 39-123$ to -156 (Interim Supp. 1974). Five states have constitutional provisions concerning tax sales. ILL. Consr. art. 9, $\$ 8 ;$ LA. Consr. art. 10, $\$ 11$; Miss. Const. $\$ 79 ;$ Mo. Const. art. 10, $\$ 13 ;$ W. VA. Const. art. 13, $\$ \$ 3-6$.

The only provisions cited above are those whose major subject is tax sales. Special provisions concerning tax sales may be found in other sections of a state's code or constitution. See, e.g., N.Y. MrL. LAw \$ 314 (McKinney Supp. 1974); WYo. Const. art. 19, \$ 9.

Also, tax sales in a particular locality may be governed by a local law not appearing in the state codc. See, e.g., ch. 559, [1902] Laws of N.Y. 1329, as amended by ch. 474, [1918] Laws of N.Y. 1534; ch. 111, [1920] Laws of N.Y. 184; ch. 200, [1922] Laws of N.Y. 520; ch. 800, [1937] Laws of N.Y. 1770; ch. 712, [1943] Laws of N.X. 2373, 2394; ch. 342, [1944] Laws of N.Y. 763 (Oneida County, New York).

2. In some states, the tax sale is, in theory, an auction sale to the highest cash bidder (see, e.g., HAwaII REv. STAT. $\$ 246-56$ (Supp. 1974)) or to the person who will accept the smallest fractional interest in the property for payment of the back taxes (see, e.g., MicH. Comp. LAws ANN. \$ 211.70 (Supp. 1974)). In other states, the property is simply sold outright for the amount of the unpaid taxes. See, e.g., ORE. REv. STAT. $\$ 312.100$ (1973). 
as the owner will lose his property for taxes equalling only a small fraction of its true value, while the tax sale purchaser will reap a decided windfall. ${ }^{3}$

In several states there is a serious constitutional question concerning the adequacy of the notice given to the owner of property about to be sold at a tax sale. In 21 jurisdictions it is possible to complete the entire tax sale procedure with no notice to interested parties other than by publication (or posting at the courthouse, or both). ${ }^{*}$ Such a practice raises the distinct possibility that the owner will lose his property without ever having known what was happening. This Note will examine the question of whether notice solely by publication is adequate to meet the constitutional standards of procedural due process of law.

\section{The Development of the Issue}

In a series of cases decided near the turn of the century, the Supreme Court held that notice by publication in tax sale proceedings did not violate the Due Process Clause of the Fourteenth Amendment. ${ }^{5}$ The decisions were handed down at a time when the procedural due process doctrines of Pennoyer $v$. Neff ${ }^{\mathfrak{B}}$ were in their heyday. In that case, Justice Field expounded for the Court a strongly territorial theory of state jurisdiction. Each state possessed complete authority over all persons and property within its borders, and had no authority over persons or property outside its borders. ${ }^{7}$ In particular, process of the courts of one state could not be served outside that state. ${ }^{8}$

3. See, e.g., Wager v. Lind, 389 F. Supp. 213, 214 (S.D.N.Y. 1975) (home worth $\$ 15,000$ owned by widow with seven children sold for $\$ 174.02$ in back taxes); Nelson v. City of New York, 352 U.S. 103, $105 \&$ n.2, $106 \&$ n.5 (1956) (two properties worth $\$ 52,000$ sold for delinquency of $\$ 3,000)$.

4. The 21 jurisdictions are Alabama, Arkansas, District of Columbia, Georgia, Hawaii, Iowa, Maryland, Michigan, Minnesota, Mississippi, Missouri, Nebraska, New Jersey, New York, Oregon, Rhode Island, South Carolina, South Dakota, Tennessee, Texas, and West Virginia. See statutes cited in note 1 supra. In Arkansas and Oregon, publication is the only form of notice provided in all cases. In the other 19 jurisdictions, certain owners will receive personal notice (by mail or personal service), while others will not. See, e.g., N.Y. Real Prop. TaX LAw $\$ \$ 1100-1174$ (McKinney Supp. 1974); R.I. Gen. Laws ANN. $\$ \$ 44-9-9$ to -10 (Supp. 1974); Ala. CODE ANN. tit. 51, $\$ 316$ (Supp. 1973).

5. Longyear v. Toolan, 209 U.S. 414 (1908); Ballard v. Hunter, 204 U.S. 241 (1907); Leigh v. Green, 193 U.S. 79 (1904). While Winona \& St. Peter Land Co. v. Minnesota, 159 U.S. 526 (1895), approved this proposition in dictum, that case involved only a judgment for the amount of back taxes due, not a tax sale. The land company could still have avoided a sale of its property simply by paying the amount of the judgment. Ch. $1, \$ 81$, [1878] Gen. Laws of Minn. 17, 51 .

6. 95 U.S. 714 (1878).

7. Id. at 722 .

8. Id. at 727. The doctrine failed to distinguish between process compelling a nonresident to appear and notice simply informing him of the action against his property. 
This doctrine created a dilemma in the case of property located within a state but owned by a nonresident. Since the property is within the state, the state courts should have jurisdiction to decide disputes concerning it. But since the owner is a nonresident, he cannot be served with process and made to defend an action brought against him. The solution to this dilemma was found in the concept of the proceeding in rem, ${ }^{0}$ a proceeding directly against the property rather than against the owner of the property. Since the nonresident owner could not be served with process, constructive notice by publication within the state was deemed sufficient. ${ }^{10}$

This rule was soon extended to all in rem proceedings, whether involving property owned by nonresidents or residents. ${ }^{11}$ The justification for the rule, grounded in the fiction of a proceeding against the land itself, was supplemented by the "caretaker theory." Owners of property were held to a duty to keep themselves informed of any proceedings affecting it. ${ }^{12}$ Thus, the general rule became that notice by publication was constitutionally adequate in all proceedings in rem, and tax sales were considered proceedings in rem. ${ }^{13}$

As American society became more mobile, it became apparent that the strongly territorial theory of state jurisdiction was no longer viable. ${ }^{14}$ As a result, the Pennoyer theory has been replaced by the "minimum contacts" theory of International Shoe Co. v. Washington. ${ }^{\text {t5 }}$ The rule that the process of a state may not be served beyond its borders is a relic of the past; today, process is routinely served outside a state under the now familiar "long-arm" statutes. And the rule that notice by publication is adequate for proceedings in rem was discarded in Mullane v. Central Hanover Bank \& Trust Co. ${ }^{16}$

9. Id. at 733-34. See Ballard v. Hunter, 204 U.S. 241, 254 (1907); Huling v. Kaw Valley Ry. \& Improvement Co., 130 U.S. 559, 563-64 (1889).

10. 95 U.S. at 727. As the doctrine was originally stated in Pennoyer, "seizure" of the property was required in addition to the published notice. Id. But the "seizure" requirement was later abandoned. Leigh v. Green, 193 U.S. 79, 91-92 (1904).

11. Leigh v. Green, 193 U.S. 79, 92 (1904). See North Laramie Land Co. v. Hoffman, 268 U.S. 276, 283 (1925); Longyear v. Toolan, 209 U.S. 414, 417-18 (1908); Winona \& St. Peter Land Co. v. Minnesota, I59 U.S. 526, 537-38 (1895).

12. North Laramie Land Co. v. Hoffman, 268 U.S. 276, 283 (1925); Longycar v. Toolan, 209 U.S. 414, 418 (1908); Ballard v. Hunter, 204 U.S. 241, 262 (1907); Huling v. Kaw Valley Ry. \& Improvement Co., 130 U.S. 559, 564 (1889).

13. Ballard v. Hunter, 204 U.S. 241, 258 (1907); Leigh v. Green, 193 U.S. 79, 90 (1904). It was also said that special deference was warranted when the state was exercising the power of taxation. Leigh v. Green, supra at 87-89.

14. For a cogent critique of Pennoyer, and a proposal to abolish the in rem/in personam distinction, see Hazard, A General Theory of State-Court Jurisdiction, 1965 Sup. CT. Rev. 241.

15. 326 U.S. 310 (1945). See Hazard, supra note 14; Kurland, The Supreme Court, the Due Process Clause and the In Personam Jurisdiction of State Courts, 25 U. CHI. L. REv. 569 (1958); Developments in the Law-State-Court Jurisdiction, 73 Harv. L. REv. 909 (1960).

16. 339 U.S. 306 (1950). 
Mullane involved a proceeding for the judicial settlement of the accounts of a common trust fund. The only notice given to the beneficiaries was by publication in a local newspaper. It was argued that this form of notice was justified because the proceeding was in rem. ${ }^{17}$ In a landmark opinion, the Supreme Court held that the classification of a proceeding as in rem or in personam was irrelevant for determining the constitutional sufficiency of the notice given.18 The Court laid down the general principle that notice in all proceedings must be "reasonably calculated, under all the circumstances, to apprise interested parties of the pendency of the action . . ."19

Observing that publication is an extremely poor form of notice,,$^{20}$ the Court nevertheless approved of such notice as to those persons whose "whereabouts could not with due diligence be ascertained," simply because no better form of notice was possible. ${ }^{21}$ But the Court ruled that when the names and addresses of persons affected by a proceeding were at hand, "the reasons disappear for resort to means less likely than the mails to apprise them of its pendency." ${ }_{22}$ As to such persons, the Court held that a serious effort to provide personal notice, at least by ordinary mail, was required. ${ }^{23}$

It might have been possible to read the Mullane case narrowly. On its facts, it did involve a proceeding which was on the borderline of the traditional distinction between in rem and in personam actions. But later cases have applied the Mullane principles to bankruptcy, ${ }^{24}$ eminent domain, ${ }^{25}$ and automobile forfeiture ${ }^{26}$ proceedings, all of which were clearly in rem under the traditional distinction.

17. Brief for Appellee Central Hanover Bank \& Trust Co. at 13-42, Brief of Respondent Special Guardian and Attorney for Infants, Etc. Having an Interest in Trust Principal at 4-11, Brief of New York State Bankers Association as Amicus Curiae at 7-11, Mullane v. Central Hanover Bank \& Trust Co., 339 U.S. 306 (1950).

18. 339 U.S. at 312-13.

19. Id. at 314. The Court added: "The means employed must be such as one desirous of actually informing the absentee might reasonably adopt to accomplish it." Id. at 315 .

20. Id. at 315 .

21. Id. at 317 .

22. Id. at 318 .

23. Id. at $318,319$.

24. City of New York v. New York, N.H. \& H.R.R., 344 U.S. 293 (1953) (notice by publication to creditor whose name and address are known held inadequate).

25. Schroeder v. City of New York, 371 U.S. 208 (1962) (notice by publication and by the posting of 22 notices along the route of the condemnation unconstitutional); Walker v. City of Hutchinson, 352 U.S. 112 (1956) (notice by publication to landowncr whose name was known unconstitutional). In Walker, the Court distinguished, in such a way as to suggest an overruling of, two early cases (North Laramie Land Co. v. Hoffman, 268 U.S. 276 (1925); Huling v. Kaw Valley Ry. \& Improvement Co., 130 U.S. 559 (1889)) which had upheld notice by publication in condemnation proceedings. 352 U.S. at 116 \& n.6.

26. Robinson v. Hanrahan, 409 U.S. 38 (1972) (per curiam) (notice by certified mail addressed to owner's residence unconstitutional when state knew owner was being held in the county jail). 
These cases make it clear that the Supreme Court has given broad application $^{27}$ to the standards enunciated in Mullane. ${ }^{28}$ Nevertheless, in several recent cases, state courts in Oklahoma, ${ }^{29}$ Oregon, ${ }^{30}$ Michigan $^{31}$ and New York ${ }^{32}$ have adhered to the turn of the century cases discussed earlier and have declined to apply Mullane to tax sale proceedings. On the other hand, state courts in Kansas ${ }^{33}$ and Arizona, ${ }^{34}$ and a federal district court in Oregon, ${ }^{35}$ recently have applied Mullane to tax sales and have held notice by publication unconstitutional. ${ }^{36}$

Two recent cases in which state supreme courts upheld notice by publication in tax sale proceedings were appealed to the United States Supreme Court. In the Oklahoma case, Paschall v. Christie-Stewart, Inc. ${ }^{37}$ probable jurisdiction was noted, and the case was briefed and orally argued. Although the Oklahoma supreme court's opinion had addressed only the notice question, the briefs, record, and oral argument revealed that there might have been an adequate state ground to support the result. Therefore, the Supreme Court declined to decide

27. "The general rule that emerges from the Mullane case is that notice by publication is not enough with respect to a person whose name and address are known or very easily ascertainable . . . " Schroeder v. City of New York, 371 U.S. 208, 212-13 (1962). See Note, Requirements of Notice in In Rem Proceedings, 70 HaRv. L. Rev. 1257 (1957); Note, Due Process of Law and Notice by Publication, 32 IND. L.J. 469 (1957).

28. It can be argued that the Supreme Court has already held Mullane applicable to tax sales. Covey v. Town of Somers, 351 U.S. 141, 146 (1956) (notice of a tax sale by publication, posting, and mail to a known incompetent unconstitutional; Mullane quoted for the applicable standard). See Walker v. City of Hutchinson, 352 U.S. 112, 115 n.4 (1956); cf. Nelson v. Gity of New York, 352 U.S. 103 (1956). In Nelson, the Court upheld a tax sale, dwelling at length on the adequacy of the notice provided. Id. at 105, 107-09, 110 . However, the tendency has been to read Covey narrowly, as having significance only for the case of a known incompetent. See, e.g., Note, Marketable Title in New York State: Tax Deeds, 9 Syracuse L. Rev. 69, 75, 82 (1957); 23 Brooklyn L. Rev. 145 (1956); 6 Buffalo L. REv. 345 (1957).

29. Christie-Stewart, Inc. v. Paschall, 502 P.2d 1265 (Okla. 1972), vacated and remanded, 414 U.S. 100 (1973).

30. Úmatilla County v. Porter, 12 Ore. App. 393, 507 P.2d 406 (1973).

31. Dow v. State, 46 Mich. App. 101, 207 N.W.2d 441, leave to appeal granted, 389 Mich. 817 (1973).

32. Botens v. Aronauer, 32 N.Y.2d 243, 298 N.E.2d 73, 344 N.Y.S.2d 892, appeal dismissed, 414 U.S. 1059 (1973).

33. Board of Sedgwick County Comm'rs v. Fugate, 210 Kan. 185, 499 P.2d 1101 (1972) (per curiam); Chapin v. Aylward, 204 Kan. 448, 464 P.2d 177 (1970); Pierce v. Board of County Comm'rs, 200 Kan. 74, 434 P.2d 858 (1967).

34. Laz v. Southwestern Land Co., 97 Ariz. 69, 397 P.2d 52 (1964); Johnson v. Mock, 19 Ariz. App. 283, 506 P.2d 1068 (1973).

35. Scoggin v. Schrunk, 34t F. Supp. 463 (D. Ore. 1971). Although the opinion does not cite Mullane, it is based on the same principles.

36. The federal court in Oregon went even further. Concluding that " $[t]$ here is a correlation between the notice a taxpayer is entitled to receive and the extent of the loss he might suffer by lack of adequate notice," the court held that notice by mail on two separate occasions prior to the tax sale, in addition to published notice, was unconstitutional where the owner stood to lose property worth in excess of $\$ 10,000$ to satisfy a tax lien of $\$ 209.344 \mathrm{~F}$. Supp. at 470 .

37. 414 U.S. 100 (1973). 
the notice issue, ${ }^{38}$ and instead vacated the judgment below and remanded the case for a decision on the state issue. ${ }^{39}$

In the New York case, Botens $v$. Aronauer, ${ }^{40}$ the appeal was dismissed for want of a substantial federal question. This might be interpreted as an approval of notice by publication, for the New York Court of Appeals' opinion had explicitly upheld such notice. But an examination of the record in Botens shows that the case did not really involve notice by publication alone. Although the applicable statutes required only published notice, it was the standard practice of the county treasurer to mail notice before the tax sale to all owners whose land was to be sold. ${ }^{41} \mathrm{~A}$ second notice was mailed during the redemption period. ${ }^{42}$ The appellants denied receiving the notice of the sale, but did not deny receiving the redemption notice. ${ }^{43}$ These facts were brought out in the appeal papers filed with the Supreme Court by the appellees. ${ }^{44}$ Thus, it would appear that the dismissal of the appeal ${ }^{45}$ meant only that the Supreme Court did not think that

38. Justice Douglas, joined by Justice Stewart, argued in dissent that the potential state ground was insubstantial, and that the Court should reach the merits. 414 U.S. at 102-04. The Court's reluctance to reach the merits may have been due to the fact that the appellants were the owners of a severed mineral interest, not the surface owner whose name and address appeared on the tax rolls. See notes 65,68 infra. Also, the Court may have been concerned about upsetting thousands of titles based on tax deeds. See pp. 1516-17 infra.

39. On remand, the Oklahoma supreme court held that there was an adequate state ground to support its earlier decision. Christie-Stewart, Inc. v. Paschall, $45 \mathrm{f}$. OKLA. B. Ass'N 2523 (Okla. Nov. 5, 1974).

40. 414 U.S. 1059, dismissing appeal from 32 N.Y.2d 243, 298 N.E.2d 73, 344 N.Y.S.2d $892(1973)$.

41. Record on Appeal at 66, 70, Botens v. Aronater, 32 N.Y.2d 243, 298 N.E.2d 73, 344 N.Y.S.2d 892 (1973). However, the treasurer was unable to produce a copy of the specific notice sent to the appellants due to a five year records retention policy. Record on Appeal at 68 .

42. Record on Appeal at 68, 72, 73. The treasurer did produce a copy of the redemption notice sent to the appellants; a copy appears in the record. Id. at 75 .

43. Record on Appeal at 26-28. The appellants only denied receiving notice of the time when the redemption period would end. $I d$. at 27,28 . The redemption notice specified the date of the tax sale but not the date on which the redemption period would expire. Id. at 75. In its opinion, the New York Court of Appeals stated that "it is conceded that [appellants] had not actually received the notice of redemption following the sale ..." 32 N.Y.2d at 247,298 N.E.2d at 74,344 N.Y.S.2d at 894 . This statement is simply incorrect.

44. Appellee's Response to Jurisdictional Statement and Motion to Affirm at 1.2, Motion to Dismiss or Affirm by the Attorney General of the State of New York at 3,6 \& n.*, Botens v. Aronauer, 414 U.S. 1059 (1973).

45. It has been said that dismissal of an appeal for want of a substantial federal question is a decision on the merits with full precedential effect. See, e.g., Mcrcado v. Rockefeller, 502 F.2d 666, 673 (2d Cir. 1974), cert. denied, 95 S. Ct. 1120 (1975). Other eminent commentators have expressed a contrary view. See, e.g., STudy Grour oN THE Caseload of the Supreme Court, Federal Judicial Center, Report 25-26 (1972); cf. Edelman v. Jordan, 415 U.S. 651, 671 (1974). In any event, the dismissal in Botens is no authority for notice by publication, since mail notice was given in that case. Paschall, which expressly left the notice question open, was decided only two weeks before Botens. 
a case in which mail notice was actually given was a good case for deciding the constitutionality of notice solely by publication..$^{40}$

\section{Justifications for Notice Solely by Publication}

In Mullane the Supreme Court stated that the ultimate test of the adequacy of notice is a balancing test: "Against th [e] interest of the State we must balance the individual interest sought to be protected by the Fourteenth Amendment." 47 In Mullane and every subsequent case $^{4 \$}$ the Court has struck this balance against notice solely by publication when the name and address of the person whose rights were being affected were readily available. In almost every tax sale case the name and address of the property owner will be readily ascertainable, either from the tax rolls, the county land records, or otherwise. A direct application of the Mullane doctrine would lead to the conclusion that notice by publication alone is unconstitutional and that some form of personal notice by mail must be provided. Therefore, if notice solely by publication is to be upheld, it is necessary to determine whether there are any distinguishing features of the tax sale which would justify a different balance in favor of notice by publication alone.

\section{A. The Delinquent Taxpayer Knows that his Property will be Sold}

The main argument which has been used to distinguish tax sales from Mullane is that the owner who does not pay his taxes knows that his property will be sold as a result. It is an argument which has appeared in all four of the recent state court opinions upholding notice by publication. ${ }^{49}$

The only basis for the presumption that the delinquent taxpayer knows what will happen is the general legal fiction that "everyone knows the law." In reality, this is a rather dubious assumption. Since landowners will have had prior experience with the annual assessment of taxes on their property, it is safe to assume that they will know

46. The issue is likely to reach the Supreme Court again soon. It is now pending before a three-judge federal district court. Wager v. Lind, 989 F. Supp. 213 (S.D.N.Y. 1975) (order for the convening of a three-judge court).

47. 339 U.S. at 314 .

48. See cases cited in notes 24-26 supra.

49. Christie-Stewart, Inc. v. Paschall, 502 P.2d 1265, 1266-67 (Okla. 1972); Umatilla County v. Porter, 12 Ore. App. 393, 395, 396, 397, 507 P.2d 406, 407, 408 (1973); Dow v. State, 46 Mich. App. 101, 107, 108, 207 N.W.2d 441, 444 (1973); Botens v. Aronauer, 32 N.Y.2d 243, 249, 298 N.E.2d 73, 75, 344 N.Y.S.2d 892, 895 (1973). 
that taxes are due each year on their land. But, since most owners pay their taxes every year, they will not have had prior experience with the tax sale system; it is doubtful that they will know the consequences of missing a tax payment.

It might still be argued that ignorance of consequences is no excuse, that the law may assume knowledge of its provisions. But this argument fails to distinguish Mullane for two reasons. First, Mullane required personal notice despite knowledge by the individuals that their property interests were being affected. ${ }^{50}$ The common trust fund involved in Mullane existed under specific statutory authorization. ${ }^{.11}$ The statute required the trustee to make application for the judicial settlement of his accounts 12 to 15 months after the fund was established and triennially thereafter.52 The statute also required that the beneficiaries be mailed a copy of those portions of the statute relating to the judicial settlement of the accounts. ${ }^{53}$ Thus, in Mullane, the general legal fiction that everyone knows the law actually had some basis in fact. The beneficiaries knew that periodic judicial settlements would be taking place, and even had a fairly good idea of when the proceedings would occur. Yet the possibility that the mailing of copies of the statute might serve as adequate notice of the later proceedings was dismissed out of hand by the Supreme Court. ${ }^{54}$ If the actual mailing of a copy of the statute is not adequate notice of later proceedings under it, surely the fiction that everyone knows the law fares no better.

Second, the argument that an owner who does not pay his taxes knows that his land will be sold assumes what should be its conclusion-that the taxes actually were not paid. Any tax sale procedure necessarily involves a determination that the taxes were in fact not paid. ${ }^{55}$ At least in the first instance, this is an administrative determination made by local officials, who can and do make mistakes. ${ }^{50} \mathrm{~A}$

50. But see Botens v. Aronauer, 32 N.X.2d 243, 249, 298 N.E.2d 73, 75, 344 N.Y.S.2d 892, 896 (1973). Botens is simply inaccurate on this point.

51. 339 U.S. at 308 .

52. Id. at 309 .

53. Id. at 310 .

54. Id. at 318 .

55. See Legg, Tax Sales and the Constilution, 20 OKLA. L. REv. 365, 374-75 (1967). In some states, this determination is made judicially (see, e.g., ORE. Rev. STAT. $\$ \$ 312.090-.100$ (1973)); in other states, administratively (see, e.g., N.Y. REAL Pror. TAX LAW \$\$ 1000-1006 (McKinney Supp. 1974)). This difference is irrelevant for purposes of determining the adequacy of the notice provided. The Supreme Court has applied the Mullane standards to both cases involving judicial proceedings (Mullane itself) and administrative proceedings (Walker v. City of Hutchinson, 352 U.S. 112 (1956)).

56. For an almost comic example of this, see Ponder v. Ebey, 194 Okla. 407, 152 P.2d 268 (1944). In that case, the owner made no less than six separate attempts to pay his taxes and have that fact recorded by the county treasurer. Nonetheless, his land was sold by the county treasurer for the nonpayment of taxes. Fortunately, he did succeed in 
determination that taxes have not been paid cannot be assumed to be correct until the owner is notified of the determination and given an opportunity to challenge it. ${ }^{57}$ An owner who has in fact paid his taxes will have absolutely no reason to expect his land to be sold, even if he is completely familiar with the applicable tax sale statute. ${ }^{58}$ Thus, the argument that a delinquent taxpayer knows the law or is ignorant at his peril does not successfully distinguish tax sales from Mullane. ${ }^{58}$

\section{B. The Government's Need to Collect Revenue}

A second major argument used to distinguish tax sale proceedings from Mullane is that the state has an important need ${ }^{60}$ to collect the taxes due it. ${ }^{\theta 1}$ When real estate tax delinquency reached crisis proportions during the Depression, several states enacted laws authorizing in rem tax foreclosure proceedings to supplement the existing in personam foreclosure remedies. ${ }^{62}$ These laws were designed to reduce

getting his property back, but only after several years of litigation. For a case in which an owner who had paid his taxes did not succeed in getting his property back, see Rogers v. Dent, 292 Mo. 576, 239 S.W. 1074 (1922).

57. For the same reason, the argument that notice by publication is justified because the delinquent taxpayer is a wrongdoer (see W. VA. CODE ANN. \$ 11 A-3-1 (1974)) must be rejected. Also, the notion that a wrongdoer is entitled to less notice than others could not have survived Robinson v. Hanrahan, 409 U.S. 38 (1972). The appellant in that case was a convicted robber, and the proceeding was for the forfeiture of his car, which had been used in the robbery. The Supreme Court held the notice unconstitutional, applying Mullane.

58. Many states provide a longer statute of limitations for challenging a tax deed if the challenge is based on a claim that the taxes had been paid. See, e.g., N.Y. REAL Prop. TAX LAw $\S 1020(3)$ (a) (McKinney Supp. 1974). But a longer statute of limitations will not do an owner much good if he has no knowledge of the tax sale and if, as would be good strategy, the tax sale purchaser "lies low" awaiting his windfall. For the same reason, the existence of the redemption period will not justify inadequate notice of the tax sale.

59. Another argument made is that notice of (and an opportunity to be heard on) the initial imposition of the taxes is sufficient notice of the tax sale proceedings. Botens $v$. Aronauer, 32 N.Y.2d 243, 248-49, 298 N.E.2d 73, 75, 344 N.Y.S.2d 892, 895 (1973). The only way to make any sense of this argument is by adding the proposition that an owner who does not pay his taxes knows what will happen. Thus, this argument is simply a particular form of the argument just considered.

60. While the traditional deference to the taxation power, see note 13 supra, remains with respect to substantive policy (see, e.g., Kahn v. Shevin, 416 U.S. 351, 355-56 (1974)), it has disappeared with respect to questions of notice. See Wisconsin Elec. Power Co. v. City of Milwauke, 352 U.S. 948 (1956) (per curiam), on remand, 275 Wis. 121, 81, N.W.2d 298 (195\%) (Mullane applied to a special tax assessment proceeding); Nelson v. City of New York, 352 U.S. 103 (1956); Covey v. Town of Somers, 351 U.S. 141 (1956).

61. See Dow v. State, 46 Mich. App. 101, 108-09, 207 N.W.2d 441, 444 (1973); Spitcaufsky v. Hatten, 353 Mo. 94, 111, 182 S.W.2d 86, 96 (1944); Umatilla County v. Porter, 12 Ore. App. 393, 396, 507 P.2d 406, 408 (1973).

It is sometimes said that the state has a need to collect taxes speedily. See Dow v. State, supra. This is dubious, as the asset (the real property) securing the tax lien will not suddenly disappear, and the state can borrow if it needs immediate cash. Also, the provision of adequate notice need not delay the timing of the tax sale proceedings at all.

62. The National Municipal League published a model in rem foreclosure law in 1935. Comm. on a Model Tax Collection Law, National Municipal League, $A$ Model Real Property Tax Collection Law, 24 NAT'L MUN. REv. 289 (1935) [hereinafter cited as 1935 
the prohibitive $\operatorname{cost}^{63}$ of the in personam procedures. ${ }^{64}$ The in rem method reduced costs by, inter alia, eliminating the requirement of personal service on all interested parties and the need for a title search to determine who those parties were. ${ }^{65}$

While these laws may have been addressed to a real problem, ${ }^{03}$ it is important to distinguish between mail notice of a proceeding and personal service of process. The mail notice required by Mullane is far less costly than regular personal service. ${ }^{67} \mathrm{~A}$ requirement of mail

Model Law]. A revised edition was issued in 1954. Comm. on a Program of Model Fiscal legislation, National Municipal leagtie, Model Real Property Tax Collection LAw (2d ed. 1954) [hereinafter cited as 1954 MODEL LAw]. Both model laws require only notice by publication. 1935 Model LAw $\$ \$ 24,46 ; 1954$ Model LAw art. VI, $\$ 5$, art. IX, $\$ 3$. On the history of the model law and state adoptions of statutes based on it, see 1954 Model LAW v, xii-xvi.

Statutes requiring only notice by publication were upheld by several state supreme courts. See Gathwright v. Mayor \& City Council, 181 Md. 362, 30 A.2d 252 (1943); Spitcaufsky v. Hatten, 353 Mo. 94, 182 S.W.2d 86 (1944); City of Newark v. Yeskel, 5 N.J. 313, 74 A.2d 883 (1950). Two cases from New York were taken to the Supreme Court. City of New Rochelle v. Echo Bay Waterfront Corp., 294 N.Y. 678, 60 N.E.2d 838, cert. denied, 326 U.S. 720 (1945); Delavan Home \& Land Co. v. County of Erie, 294 N.Y. 847, 62 N.E.2d 396, appeal dismissed, 326 U.S. 681 (1945) (dismissed for want of a substantial federal question, citing Winona \& St. Peter Land Co. v. Minnesota, 159 U.S. 526 (1895) (see note 5 supra)). These two Supreme Court actions were interpreted by some as con: stituting a general approval of in rem tax foreclosure statutes. In Rem Foreclosure of Tax Liens, in Municipalities and THe Law in ACTION 1946, at 511, 516, 519-20 (C. Rhyne ed. 1946). However, these actions offer no support for notice by publication because (1) neither involved a full decision on the merits, (2) both came before the decision in Mullane, and (3) the New York statutes involved required mail notice to the owner. N.Y. Tax Law $\$ 165-b$, ch. 692, \$2, [1939] Laws of N.Y. 1642, 1653 (now N.Y. REAL PRor. TAX LAw \$1124 (McKinney Supp. 1974)); Erie County Tax Act \$11-13.0, ch. 789, \$ 18, [1944] Laws of N.Y. $1743,1749-50$.

Although the Depression crisis has passed, one recent Note has argued that the situation in certain urban areas of New Jersey is such that the New Jersey in rem foreclosure statute (which requires only notice by publication) should be extended to cases to which it does not now apply. Note, Tax Sale Law in New Jersey: A Re-Examination, 26 RutGers L. REv. 266 (1973). In 1971, the Missouri legislature enacted an in rem foreclosure statute applicable to St. Louis which requires only notice by publication. Mo. ANN. STAT. \$§ 92.700-.920 (Supp. 1975). See Langsdorf, Urban Decay, Property Tax Delinquency: A Solution in St. Louis, 5 URB. LAw. 729 (1973).

63. See A. Hillhouse \& C. Chatters, Tax-Reverted Properties in Urbin Areis 11, 13 , 18.20 (1942); Xanthaky, Improvements in Foreclosure Procedure, in Property TAXes 262, 262-63 (Tax Policy League ed. 1940).

64. See 1954 MODEL LAw, supra note 62, at xviii-xix. In one city in New York, the average foreclosure cost per parcel was $\$ 4.60$ under the in rem procedure, as compared to $\$ 101$ under the in personam procedure. Xanthaky, supra note 63 , at $273-7.4$.

65. 1954 Modfr. LAw, supra note 62, at xix. However, Xanthaky's data show that the title search and personal service accounted for only $\$ 21$ of the $\$ 101$ cost of the in personam procedure. Xanthaky, supra note 63 , at 27 . Thus, substantial savings could have been effected without cutting back at all on the notice given. $\Lambda$ s a matter of due process, notice is the last thing which should be cut back. A person who knows his property interests are about to be cut off but does nothing to prevent it has much less to complain about than a person whose interests are cut off without his knowledge because the only "notice" given him was by publication.

66. There is some doubt whether the in personam procedures were really unworkable. For a description of a successful property tax collection effort during the Depression using an in personam procedure, see Kemp, $A$ Survey of Procedures for the Collection of Delinquent Taxes, in Municipalities and THE LAw IN ACTION IN 1941, at 353, 358-61 (C. Rhyne ed. 1942). See generally A. Hillhouse \& C. Chatrers, supra note 63, at 31-41.

67. The $\$ 4.60$ cost for the in rem procedure, see note 64 supra, included the cost of mail notice to the owner, which the New York in rem statute required. Xanthaky, supra note 63, at 269. Xanthaky estimated the cost of this notice to be "about a dime." Id. 
notice would not add appreciably to the cost of an in rem tax foreclosure proceeding. ${ }^{88}$ Even if the costs were significant, they could be added to the amount of the back taxes, to be recovered when the owner paid up or when the property was sold. Certainly the individual's strong interest in mail notice as compared to published notice outweighs any small additional expense to the government. ${ }^{69}$

\section{The Caretaker Theory}

The recent tax sale cases approving notice by publication have relied in part upon the caretaker theory: the owner of property is under

68. While the cost of sending notice by mail would not be substantial, the cost of a title search to determine the interested parties might be substantial, depending on how the land records are organized. Mullane approved of notice by publication as to those trust fund beneficiaries whose interests "could be discovered" but "do not in due course of business come to knowledge of the common trustee." 339 U.S. at 317. However, this holding was based in part on a representation theory (id. at 319) which would not apply to the usual tax sale case. In any event, Mullane makes it clear that the fact that the identities of certain interested parties (such as lienholders or owners of severed mineral interests) may be too difficult to determine is no excuse for failing to provide mail notice to those parties whose interests and whereabouts are known (id. at 318), in particular, the owner of the property whose name and address appear on the tax rolls.

69. The balance to be struck between the owner's interest and the government's interest can be illuminated by comparing the tax sale situation to Goldberg v. Kelly, 397 U.S. $254(1970)$. In that case, welfare recipients claimed that due process requires a full evidentiary hearing prior to the termination of welfare benefits, in addition to the personal notice, informal hearing, opportunity for review by a higher official, and posttermination full hearing which were already provided. Explicitly applying a balancing test, the Court held that the recipient's interest in the pretermination full hearing, combined with the government's interest in preventing the erroneous termination of payments, outweighed the government's interest in preventing payments to ineligible recipients.

Each of the factors weighed in Goldberg has a direct counterpart in the tax sale situation. The government's interest in preventing illegal welfare payments and the interest in collecting tax revenue are simply two sides of the same coin-protection of the public fisc. (There are indications that the Court gives greater deference to the taxation power than to the spending power. Compare Kahn v. Shevin, 416 U.S. 351 (1974) with Weinberger v. Wiesenfeld, $95 \mathrm{~S}$. Ct. 1225 (1975). But compare Vlandis v. Kline, 412 U.S. 441 , 452.53 (1973) with Austin v. New Hampshire, 95 S. Ct. 1191 (1975). Cf. Marchetti v. United States, 390 U.S. 39, 58 (1968). See note 60 supra.) But the government interest in collecting property taxes is much weaker because the tax lien is secured by an immovable asset (the real property), whereas illegal payments to ineligible welfare recipients are unlikely ever to be recovered.

On the other side of the scales, the government surely has an interest in preventing the erroneous tax sale of an owner's property. And the difference to the individual between mail notice (which is almost certain to reach him) and published notice (which is usually no notice at all) is much greater than the difference in Goldberg between a full hearing and the informal hearing already provided.

The Court struck the balance in Goldberg in favor of the due process claim. It follows that the same balance must be struck in the tax sale situation.

At a higher level of generalization, it can be said that the welfare recipient's interest is in the continued receipt of payments, while the property owner's interest is in the retention of his property. Which of these interests is stronger depends ultimately on one's views about private property and the welfare state. In a society where private property and the work ethic are still held in high regard, it can certainly be argued that the property owner's interest is stronger. Also, it can be strongly argued that, in a constitutional sense, the owner's interest is stronger because welfare recipients would have no constitutional claim if a state were to completely abolish its welfare program whereas property owners would have a constitutional claim if a state were to expropriate all private property. Cf. San Antonio Independent School Dist. v. Rodriguez, 411 U.S. I, $29-37$ (1973). 
a duty to watch the published notices.to see if there is anything affecting his property. ${ }^{70}$ But the caretaker theory, in this broad form, was firmly rejected in Mullane. The Court said it was "too much" to expect an individual to "examine all that is published to see if something may be tucked away in it that affects his property interests."71

One paragraph in the Mullane opinion did seem to approve a much more limited form of the caretaker theory. ${ }^{72}$ The Court suggested that, with respect to tangible property, notice by publication might be acceptable if it was used as a supplement to other action, such as seizure or entry upon real estate, which in itself might be expected to come to the owner's attention. However, this paragraph of Mullane bears little relevance to the tax sale problem, for, of the 21 jurisdictions which permit notice solely by publication, only one ${ }^{73}$ requires any kind of seizure or entry upon the land to which the published notice would be supplemental. ${ }^{74}$ In any event, it is now doubtful whether this paragraph of Mullane retains any continued vitality. ${ }^{75}$

\section{Titles Based on Tax Deeds Should Not be Upset}

The rule that notice by publication is sufficient in tax sale proceedings should be upheld, it is argued, in order to avoid upsetting "the validity of thousands of titles" based on tax deeds.70 This argument is not a justification, as such, for notice by publication, but

70. Dow v. State, 46 Mich. App. 101, 106, 108, 207 N.W.2d 441, 443, 444 (1973); Botens v. Aronauer, 32 N.Y.2d 243, 249, 298 N.E.2d 73, 75, 344 N.Y.S.2d 892, 895 (1973).

71. 339 U.S. at 320 . Another argument clearly rejected in Mullane, id. at 312-13, that notice by publication is sufficient because a tax sale is a proceeding in rem, has nevertheless been used in some of the recent tax sale cases. Botens v. Aronauer, 32 N.X.2d 243, 248, 298 N.E.2d 73, 74, 344 N.Y.S.2d 892, 895 (1973); Umatilla County v. Porter, 12 Ore. App. 393, 396, 507 P.2d 406, 408 (1973).

72. 339 U.S. at 316.

73. The South Carolina tax sale statute requires the sheriff to "[s]eize and take exclusive possession of" the real estate before the tax sale, as well as publish notice of the sale. S.C. CODE ANN. $\$ 65-2766$ (Supp. 1974).

74. Nonetheless, two recent tax sale cases have relied on this paragraph of Mullane. In Dow v. State, 46 Mich. App. 101, 107-08, 207 N.W.2d 441, 444 (1973), the court simply misread this paragraph as approving of the broad caretaker theory. In Christie-Stewart, Inc. v. Paschall, 502 P.2d 1265, 1268 (Okla. 1972), the court said that the "other action" to which notice by publication was supplemental was the existence of the tax sale statute. This is hardly the kind of "direct attack" upon property to which the Mullane paragraph referred. This logic would have justified notice by publication in Mullane itself.

75. See Robinson v. Hanrahan, 409 U.S. 38, rev'g per curiam People ex rel. Hanrahan v. One 1965 Oldsmobile, 52 Ill. 2d 37, 42, 284 N.E.2d 646, 651 (1972); Schroeder v. City of New York, 371 U.S. 208, 213-14 (1962). In both of these cases, there was a seizure to which the other notice given could be said to be supplemental. But in Schroeder, the Court rejected the notion that the seizure might itself be considered a form of notice; in Robinson, the Court did not even discuss the possibility. In both cases, the other notice given was held unconstitutional under the Mullane standard.

76. Botens v. Aronauer, 32 N.Y.2d 243, 247, 298 N.E.2d 73, 74, 344 N.Y.S.2d 892, 894 (1973). 
states that, the rule having been established in the turn of the century cases, it would be too disruptive of settled expectations to change it now. However, a holding that notice by publication is unconstitutional would not have to be applied retroactively. In similar situations, the Supreme Court has applied a new constitutional rule only prospectively. ${ }^{77}$ For example, in cases holding that property restrictions on the franchise in bond issue elections were unconstitutional, the Court gave the rulings only prospective effect in order to avoid interfering with bonds already issued following such elections.7s

Of course this is not to say that retroactive effect should be denied to a holding that notice by publication in tax sale proceedings is unconstitutional. Retroactive application of the new rule would not necessarily defeat all titles based on tax deeds. First, not every deed would be challenged; the owner may in fact have abandoned the property. Second, the doctrine of adverse possession would defeat challenges to most older deeds. ${ }^{79}$ More importantly, the purpose of giving retroactive effect to the holding of unconstitutionality would be to vindicate the principle ${ }^{80}$ that no person should be deprived of his property without adequate notice. ${ }^{81}$ In those cases where a challenge was brought, the result would be that the tax sale purchaser would lose his windfall, and the owner would be restored to the excess value of his property. This would not be an unjust result.

77. See generally Wellington, Common Law Rules and Constitutional Double Standards: Some Notes on Adjudication, 83 YALE L.J. 221, 254-61 (1973); Mishkin, The High Court, The Great IVrit, and the Due Process of Time and Law, 79 HARv. L. Rev. 56 (1965); Schwartz, Retroactivity, Reliability, and Due Process: A Reply to Professor Mishhin, 33 U. CHI. L. REv. 719 (1966); Note, Prospective Overruling and Retroactive Application in the Federal Courts, 71 YALE L.J. 907 (1962).

78. Hill v. Stone, 95 S. Ct. 1637, 1645 (1975); City of Phoenix v. Kolodziejski, 399 U.S. 204, 213-15 (1970); Cipriano v. City of Houma, 395 U.S. 701, 706 (1969).

In all of these cases, the retroactivity issue was decided in the same case in which the new constitutional rule was announced. But in other situations, the retroactivity question has been left to a later decision. See Linkletter v. Walker, 381 U.S. 618 (1965) (Mapp v. Ohio, $36 \%$ U.S. 643 (1961), given only prospective effect); G. GUNTHER \& N. Dowling, Cases and Materials on Constitutional Law 892-97 (8th ed. 1970).

79. In the majority of states where color of title is not required, the tax deed would be irrelevant once the adverse possession period had run. In the few states which require color of title, a void tax deed would satisfy this requirement. See 3 AMERICAN LAw of Property \$ 15.4(c) (A.J. Casner ed. 1952).

Special short statutes of limitations for bringing challenges to tax deeds might shield all but very recent deeds from attack. Whether the lack of constitutionally valid notice would preclude the running of a statute of limitations is a question on which the Supreme Court explicitly declined to express any view in Paschall v. Christie-Stewart, Inc., 414 U.S. 100, 102 n.4 (1973). Compare Cipriano v. City of Houma, 395 U.S. 701, 706 (1969) and City of Phoenix v. Kolodziejski, 399 U.S. 204, 214 (1970) (challenge must be brought within statutory period) with Schroeder v. City of New York, 371 U.S. 208, 210, 214 (1962) (challenge after statutory period allowed).

80. See Wellington, supra note 77 , at 256.

81. Adequate notice was described in Mullane as "[a]n elementary and fundamental requirement of due process...." 339 U.S. at 314 . 


\section{Conclusion}

As the Supreme Court said in Mullane:

Where the names and post-office addresses of those affected by a proceeding are at hand, the reasons disappear for resort to means less likely than the mails to apprise them of its pendency. ${ }^{\text {s2 }}$

The arguments for notice by publication in tax sale cases have been considered above. None justifies exempting tax sales from the Mullane rule. ${ }^{83}$ Therefore, in an appropriate case, the Supreme Court should declare that notice solely by publication in tax sale proceedings is unconstitutional. In the meantime, the legislatures in the 21 jurisdictions which now allow such notice should not wait, but should act promptly to provide at least the minimal notice required by the Constitution.

As the above-quoted passage from Mullane indicates, the minimal constitutional requirement ${ }^{84}$ appears to be notice mailed to the owner's last known address. ${ }^{85}$ However, one court has held that the owner's interest in not losing his property for taxes amounting to a fraction of its value is so strong that even greater efforts by the state are required. ${ }^{86}$ In any event, the states should go beyond the minimal constitutional requirements in order to be as certain as possible that no forefeiture of property takes place before the owner is made aware of the threat and given an opportunity to prevent his loss.

82. Id. at 318.

83. It might be argued that while none of the justifications offered by itself outweighs the individual's interest in personal notice, all of them taken together do outweigh that interest. But any such overall balancing clearly favors the individual owner. Personal notice by mail is almost certain to reach the owner; published notice is almost certain not to. And without notice, the owner may suffer the complete loss of his property for back taxes equalling a fraction of its value. On the other hand, mail notice would be only a small additional expense for the state. That mail notice would not be a major burden is indicated by the fact that 30 states already require such notice in all tax sale proceedings, and 19 of the other 21 jurisdictions provide mail notice in at least some cases. See note 4 supra.

84. See Schroeder v. City of New York, 371 U.S. 208, 214 (1962) (notice is "an obligation which the mailing of a single letter would have discharged."); Walkcr v. City of Hutchinson, 352 U.S. 112, 116 (1956) ("Even a letter would have apprised him that his property was about to be taken ....").

85. Ouestions concerning when mail notice is required (before the tax sale, before the end of the redemption period, etc.) are not considered here. If the reference in Schraeder to "a single letter" (note 84 supra) is taken literally, the absolute minimum requirement would appear to be notice mailed to the owner at some point before the tax sale procedures are completed.

86. Scoggin v. Schrunk, 344 F. Supp. 463,470 (D. Ore. 1971). See note 36 supra. 